\title{
Persistence and Degradation Pattern of Acequinocyl and Its Metabolite, Hydroxyl-acequinocyl and Fenpyroximate in Butterburs (Petasites Japonicus Max.)
}

\section{Leesun Kim}

National Institute of Agricultural Sciences

\section{Geun-Hyoung Choi}

National Institute of Agricultural Sciences

Hyun Ho Noh

National Institute of Agricultural Sciences

Taek-Gyum Kim

National Institute of Agricultural Sciences

Dal-Soon Choi

National Institute of Agricultural Sciences

Kee Sung Kyung

Chungbuk National University

Jin-Ho Ro ( $\nabla$ jhro@korea.kr)

Rural Development Administration https://orcid.org/0000-0001-9799-6884

\section{Research Article}

Keywords: acequinocyl, butterburs, residue pattern, fenpyroximate, minor crop

Posted Date: April 5th, 2021

DOI: https://doi.org/10.21203/rs.3.rs-324601/v1

License: (c) (i) This work is licensed under a Creative Commons Attribution 4.0 International License. Read Full License 
1 Persistence and degradation pattern of acequinocyl and its metabolite, 2 hydroxyl-acequinocyl and fenpyroximate in butterburs (Petasites japonicus 3 Max.)

Leesun Kim ${ }^{1}$, Geun-Hyoung Choi ${ }^{1}$, Hyun Ho Noh ${ }^{1}$, Taek-Gyum Kim ${ }^{1}$, Dal-Soon Choi $^{1}$, Kee 6 Sung Kyung ${ }^{2}$, Jin-ho Ro ${ }^{3, *}$

$7{ }^{1}$ Residual Agrochemical Assessment Division, National Institute of Agricultural Sciences, 8 Rural Development Administration, Wanju-gun, 55365, Republic of Korea

$9{ }^{2}$ Department of Environmental and Biological Chemistry, College of Agriculture, Life and 10 Environment Science, Chungbuk National University, Cheongju, 28644, Korea

$11{ }^{3}$ Technology Service Team, National Institute of Agricultural Sciences, Rural Development 12 Administration, Wanju-gun, 55365, Republic of Korea

\begin{abstract}
Degradation patterns and persistence of acequinocyl and its metabolite, hydroxyl-acequinocyl (acequinocyl-OH), and fenpyroximate residues in butterburs (Petasites japonicus Max.), one of the minor crops in Republic of Korea, were investigated during cultivation. Butterburs were planted in two plots (plot A for double dose; plot B for single dose) in a greenhouse. Each pesticide was applied to the foliage of butterburs at hourly intervals. Recoveries of acequinocyl and acequinocyl-OH were $78.6 \%-84.7 \% \pm$ relative standard deviation (RSD) $1.9 \%-4.8 \%$ and $83.7 \%-95.5 \% \pm \operatorname{RSD} 1.0 \%-3.6 \%$, respectively. The total $(\Sigma)$ of acequinocyl residues in butterburs disappeared by $96.0 \%$ at 14 days after the final application in plot A and by $75.9 \%$ at 7 days in plot B. The biological half-life of the total $(\Sigma)$ acequinocyl and fenpyroximate was 3.0 days and 4.0 days respectively. These results were used for setting maximum residue levels and safe use standards for the pesticide during butterbur cultivation. The risk assessment showed that the maximum $\%$ acceptable daily intake was $4.71 \%$ for $\Sigma$ acequinocyl and $8.81 \%$ for fenpyroximate. The theoretical maximum daily intake of $\Sigma$ acequinocyl and fenpyroximate were $24.02 \%$ and $15.24 \%$, respectively, indicating the concentrations of $\Sigma$ acequinocyl and fenpyroximate in butterburs pose no health risks to Koreans.
\end{abstract}

Keywords: acequinocyl, butterburs, residue pattern, fenpyroximate, minor crop

\footnotetext{
* Corresponding author. Tel: +82-63-238-2318; fax: +82-63-238-3819. E-mail address: jhro@korea.kr (J.-H. Ro).
} 
The definition of minor crops varies among countries owing to different agricultural environments (OECD 2014). In South Korea, crops cultivated in land smaller than 1,000 hectares are classified as minor crops (OECD 2014). Despite their small-scale farming, these minor crops are also known as high-value agricultural produce because they generally yield great economic profits to the farmers. However, timely pest control is one of the main persistent issues as only a limited number of pesticides is officially listed for each minor crop (Lee et al. 2019a). In addition, pesticide manufacturers tend not to justify the cost of registration testing or the maintenance of pesticide registration due to poor economic performance (Lamichhane et al. 2015). Therefore, farmers who grow minor crops face difficulties to find suitable pesticides for pest control. Further, unlisted pesticide residues in foods are of critical concern in food safety programs around the world; since 1998, in cooperation with the Korean Ministry of Food and Drug Safety (MFDS), the Rural Development Administration has conducted an ongoing project to select and register specific pesticides for each minor crop by carrying out field dissipation tests (Lee et al. 2019a, Lee 2013).

The minor crops butterburs (Petasites japonicus Max.) have recently garnered considerable attention owing to its high levels of nutrients (Lee et al. 2019b), antioxidants (Matsuura et al. 2002), and anti-cancer ingredients (Seo et al. 2008). As the consumption of butterburs has increased in South Korea, many farmers have started growing the crop in greenhouses. However, farmers face difficulties in controlling several types of mites, including the red spider mite (Tetranychus urticae, Koch) and snout moths (Pyrali, 12 species), due to the limited number of pesticides registered for the target plant. Among the listed pesticides, standard maximum residue levels (MRLs) were not established for some pesticides when the present study was carried out. In addition, in line with the Positive List System (PLS), fully implemented on January $1^{\text {st }}, 2019$, MRLs for some pesticides should be established to prevent 
trade disruption and settle industrial concerns in South Korea (USDA 2018).

In this study, acequinocyl (AKD-2023; 3-dodecyl-1,4-dihydro-1,4-dioxo-2-naphthyl acetate) and fenpyroximate (tert-butyl (E)-alpha-(1,3)-dimethyl-5-phenoxy-1H-pyrazol-4-yl methylene amino-oxy)-para-toluate) were selected as test pesticides for butterbur cultivation as both acaricides are known to effectively eliminate T. urticae (Suh et al. 2006) which has caused widespread economic damage by attacking around 150 species of economically significant plants (Yorulmaz Salman \&Sarıtaş 2014). To register acequinocyl and/or fenpyroximate as official pesticides for butterbur cultivation in South Korea, their dissipation patterns need to be investigated. Experimental data can be used to determine their MRLs to ensure the effective application, food safety, and environmental protection of these pesticides as well as to prepare for PLS (USDA 2018).

The mode of action of fenpyroximate is the inhibition of mitochondrial electron transport at transmembrane enzyme complex I (Marcic 2012). This pesticide has been used to cultivate a wide range of fruits, flowers, and vegetables, such as red bell peppers (Capsicum annuum), cherry tomatoes (Solanum lycopersicum var. cerasiforme), pumpkins (Cucurbita spp.), strawberries (Fragaria $\times$ ananassa), watermelons (Citrullus lanatus), roses (Rosa spp.), gerbera daisies (Gerbera jamesonii), and chrysanthemum (Chrysanthemum spp.) by controlling T. urticae (Suh et al. 2006). Acequinocyl functions through oxidative phosphorylation, and complex II and III inhibitors (Marcic 2012, Park et al. 2010). Generally, after application as a pesticide, acequinocyl and its metabolite, hydroxyl-acequinocyl (acequinocyl-OH) are analyzed. The deacetylated metabolite with a free hydroxyl group is a powerful inhibitor of the Qo center (ubiquinol oxidation site of complex III) by acting as a structural analogue of ubiquinone (Yorulmaz Salman \&Sarıtaş 2014). Residue patterns have been reported of fenpyroximate in grapes (Vitis spp.) (Malhat et al. 2013), and acequinocyl and acequinocyl-OH in grapes, lemons (Citrus $\times$ limon), pears (Pyrus spp.), tomatoes (Solanum 

Authority 2016) and perilla leaf (Perilla frutescens) (Na et al. 2012). However, to the best of our knowledge, there are no reports on the residue behavior of fenpyroximate, acequinocyl, and acequinocyl-OH during the growth of butterburs.

This study aimed 1) to understand the field dissipation pattern of acequinocyl, acequinocyl$\mathrm{OH}$, and fenpyroximate in butterburs after applying twice (plot A) and once (plot B) with two pesticides (water dispersion formulation) in greenhouses, and 2) to offer the required data for the establishment of MRLs and pre-harvest intervals (PHI) for the safe use of pesticides in cultivating butterburs. The theoretical maximum daily intake (TMDI) and estimated daily intake (EDI) for Koreans were evaluated using MRLs, food factors, residue data, and correction factors, and compared with the acceptable daily intake (ADI) in order to estimate the health risk based on pesticide exposure. Then, the carcinogenic risks of the pesticides were assessed using TMDI and adjusted EDI.

\section{Materials and methods}

\section{Chemicals and solvents}

The standard for fenpyroximate $(99.6 \%)$ was kindly provided by Dongbu FarmHannong Co., Ltd. (Seoul, South Korea). Standards of acequinocyl (98.1\%) and acequinocyl-OH (98.5\%) were obtained from Sigma-Aldrich (USA) and Agro-Kanesho (Japan), respectively. Highperformance liquid chromatography (HPLC)-grade acetone $\left(\mathrm{C}_{3} \mathrm{H}_{6} \mathrm{O}\right)$, acetonitrile $(\mathrm{MeCN})$, dichloromethane (DCM), ethyl acetate (EtOAc), $n$-hexane, distilled water (DW), acetic acid $\left(\mathrm{CH}_{3} \mathrm{COOH}\right)$, analytical-grade sodium sulfate $\left(\mathrm{NaSO}_{4}\right)$, and sodium chloride $(\mathrm{NaCl})$ were purchased from Merck (KGaA, Germany). Spiking and working calibration solutions for HPLC analysis were prepared by diluting the stock solutions with MeCN, achieving concentrations in the range of 0.1 to $10 \mathrm{mg} / \mathrm{L}$. The prepared standard solutions were stored in a refrigerator $\left(4^{\circ} \mathrm{C}\right)$. 


\section{Experimental design for greenhouse}

Butterburs were planted in a greenhouse in Nonsan, South Chungcheog Province, South Korea. The experimental area was composed of two plots (plot A for double dose; plot B for single dose), in which a random block scheme was established with three replicates (Fig. 1). Control samples were cultivated in a separate greenhouse without pesticide treatment. Commercial acequinocyl $[15 \% \mathrm{WP}]$ and fenpyroximate [5\% wettable powder (WP)] were diluted 2,000 times and 1,000 times with water, respectively, based on the manufacturer's guidelines. Each pesticide was applied to the butterbur crops at a concentration of $0.03 \mathrm{~kg}$ a.i./10a (active ingredient) at hourly intervals. They were initially sprayed on plants in plot A on April 5, 2016, and then on both plots A and B, on April 12, 2016. Butterburs were harvested at days 0, 7, 14, and 21 after the second application. After the samples were collected, they were stored in a freezer $\left(-4{ }^{\circ} \mathrm{C}\right)$ until analysis. Climatic conditions during the cultivation were monitored using a thermo-hygrometer (model Tr-72wf, T\&D Corp., Korea) inside the greenhouse. Inside temperatures ranged from 4.5 to $40.5{ }^{\circ} \mathrm{C}$, and relative humidity ranged from $58.4 \%$ to $89.9 \%$ throughout the experimental period.

\section{Sample preparation and instrumental conditions}

To extract acequinocyl, acequinocyl-OH, and fenpyroximate from the butterbur samples, acetone $(100 \mathrm{~mL})$ with $0.5 \mathrm{~mL}$ of $\mathrm{CH}_{3} \mathrm{COOH}$ was added to the pulverized butterburs $(20 \mathrm{~g})$ in a 100-mL Erlenmeyer flask. The flasks were shaken using a homogenizer (Ultra-Turrax T-25, IKA, Japan) at 10,000 rpm for 5 min. Extracts were filtered through a Büchner funnel with celite 545 (Merck KGaA, ACS grade, Germany). Using a separatory funnel, the target analytes were extracted with $100 \mathrm{~mL}$ of DCM $(\mathrm{n}=1)$ and $50 \mathrm{~mL}$ of DCM $(\mathrm{n}=2)$. The extract was dehydrated with anhydrous sodium sulfate and evaporated to dryness below $40{ }^{\circ} \mathrm{C}$ under vacuum using a rotary vacuum evaporator (1,100 series, Eyela Co. Japan). The sample was 
redissolved in $2 \mathrm{~mL}$ of $n$-hexane.

For the fenpyroximate clean-up, $\mathrm{NH}_{2}$ silica solid-phase extraction (SPE) (Mega BE-NH2, $1 \mathrm{~g}, 6$ $\mathrm{mL}$ : Agilent Technologies, USA) cartridges were activated with $5 \mathrm{~mL}$ of DCM before $2 \mathrm{~mL}$ of the sample was loaded. Then, $10 \mathrm{~mL}$ of $n$-hexane/EtOAc $(95 / 5, \mathrm{v} / \mathrm{v})$ was eluted to remove the co-extractives derived from the sample. Finally, fenpyroximate was eluted with $10 \mathrm{~mL}$ of $15 \%$ EtOAc in $n$-hexane. After the eluate was evaporated to dryness below $40{ }^{\circ} \mathrm{C}$ under vacuum, the sample was redissolved in $2 \mathrm{~mL}$ of $\mathrm{MeCN}$ for HPLC-UVD analysis. For acequinocyl and acequinocyl-OH clean-up, SPE cartridges (Bond Elut SI, 1 g, $6 \mathrm{~mL}$ : Agilent Technologies, USA) were conditioned with $5 \mathrm{~mL}$ of $n$-hexane, and $2 \mathrm{~mL}$ of the extracted sample was loaded. Then, $10 \mathrm{~mL}$ of $n$-hexane was eluted to eliminate the coextractives derived from the sample. Finally, acequinocyl and acequinocyl-OH were eluted with $10 \mathrm{~mL}$ of $10 \%$ EtOAc in $n$-hexane. After the eluate was evaporated to dryness below $40{ }^{\circ} \mathrm{C}$ under vacuum using a rotary vacuum evaporator, the sample was reconstituted in $2 \mathrm{~mL}$ of MeCN for HPLC-UVD analysis.

Instrumental analysis was performed using an HPLC system (Hewlett Packard 1100 series, USA) equipped with a binary solvent manager, an auto sampler, and UV detector (Hewlett Packard 1314A, Variable Wavelength, USA). The target compounds were separated using a C18 column (4.6 mm I.D. $\times 250 \mathrm{~mm} \mathrm{L.,} 5 \mu \mathrm{m}$ particle size, Young Jin Bio, Korea) maintained at $30{ }^{\circ} \mathrm{C}$. The mobile phase, containing a mixture of $\mathrm{MeCN}$ and $10 \mathrm{mM} \mathrm{H}_{3} \mathrm{PO}_{4}$ in DW (\%) (88:12, v/v) in isocratic mode, was used. The detection was performed at a wavelength of $270 \mathrm{~nm}$. The flow rate was $1.0 \mathrm{~mL} / \mathrm{min}$, and the injection volume was $10 \mu \mathrm{L}$.

\section{Method validation}

To validate the analytical method used in this study, recovery tests were performed by adding pesticide standards at levels of 0.1 and $0.5 \mathrm{mg} / \mathrm{kg}$ to the control samples $(\mathrm{n}=3)$. The 
repeatability of the method was evaluated by the relative standard deviation (RSD, \%) associated with the measurements of the pesticide concentration through recovery analyses. Standard calibration curves were plotted after a mixture of acequinocyl and acequinocyl-OH solution and fenpyroximate were serially diluted with $\mathrm{MeCN}$ to prepare seven different concentrations $(0.1 \mathrm{mg} / \mathrm{L}, 0.2 \mathrm{mg} / \mathrm{L}, 0.5 \mathrm{mg} / \mathrm{L}, 1.0 \mathrm{mg} / \mathrm{L}, 2.0 \mathrm{mg} / \mathrm{L}, 5.0 \mathrm{mg} / \mathrm{L}$, and $10 \mathrm{mg} / \mathrm{L})$. The limit of detection (LOD) of the target compounds was determined using a signal-to-noise ratio of 3 with reference to the background noise obtained for the blank sample, whereas the method limits of quantification (MLOQ) were determined with a signal-to-noise ratio of 10 .

\section{Formulation of dissipation pattern}

The concentration of fenpyroximate residue in the butterburs was expressed as itself, whereas the concentration of acequinocyl residue in the butterburs were expressed as the total $(\Sigma)$ of the parent compound (acequinocyl) and its metabolite (acequinocyl-OH) by the following Equation 1:

$$
\begin{gathered}
\text { Concentration of } \Sigma \text { acequincly residue }\left(\frac{\mathrm{mg}}{\mathrm{kg}}\right)=\text { acequinocyl residue }\left(\frac{\mathrm{mg}}{\mathrm{kg}}\right)+ \\
{\left[1.12 \times \text { acequinocyl }- \text { OH residue }\left(\frac{\mathrm{mg}}{\mathrm{kg}}\right)\right]}
\end{gathered}
$$

where the constant of 1.12 is the conversion factor obtained by dividing molecular weight (MW) of acequinocyl $(384.5 \mathrm{~m} / \mathrm{z})$ by MW of acequinocyl-OH $(342.5 \mathrm{~m} / \mathrm{z})$.

The dissipation pattern of the target pesticide residues in butterburs followed first-order kinetics reactions. The dissipation rate constant was determined using a first-order rate Equation 2:

$$
C_{t}=C_{0} e^{-k t}
$$

where $t$ is the number of days after pesticide application, $\mathrm{C}_{0}$ is the highest total concentration of acequinocyl residue, and $k$ is the dissipation rate constant.

Based on the equation acquired from the field data, the biological half-life in days (DT50) was 
calculated using Equation 3 (Hwang et al. 2015):

$$
\mathbf{D T}_{\mathbf{5 0}}=\ln (2) / k
$$

\section{Risk assessment}

From a potential health risk perspective, it is essential to compare pesticide exposure estimates with established toxicological criteria such as estimated daily intake (EDI). In this study, the health risk (percent acceptable daily intake; \%ADI) of the target analyte that is consumed with butterburs was calculated by the ratio of EDI to ADI. EDI is a realistic estimation of pesticide residue exposure that was calculated based on international guidelines (Chun \&Kang 2003). EDI was calculated by multiplying the high residue (HR) of daily food intake of butterburs by Koreans by age. The daily food intake of butterburs for Koreans by age was provided by the Korean Health Industry Development Institute (KHIDI Korea Health Industry Development Institute 2016). The average Korean body weight by age was acquired from the Korean Centers for Disease Control and Prevention (Prevention 2011). The EDIs were calculated using the average body weights by age. Equations 4, 5, and 6 (below) were used for the risk assessment (Kim et al. 2018).

The ADIs were determined based on the Pesticide and Veterinary Drugs Information database (http://www.foodsafetykorea.go.kr/residue/main.do) provided by the Korean Ministry of Food and Drug Safety (MFDS). In addition, the theoretical maximum daily intakes (TMDIs) of the target pesticides were calculated using the average body weight $(57.8 \mathrm{~kg}$ ) of adults (over 19 years) and MRLs in South Korea (Eq 5) and maximum residue limits (MRLs), which were provided by the Korean MFDS. TMDIs were calculated as:

$\mathrm{ADI}(\mathrm{mg} / \mathrm{kg} /$ person $)=\mathrm{ADI}(\mathrm{mg} / \mathrm{kg}) \times$ body weight/day $)$ of target compound $\times$ average body weight by age

EDI $(\mathrm{mg} / \mathrm{kg} / \mathrm{person})=$ amount of target compound $\mathrm{mg} / \mathrm{kg} \times$ daily food intake $(\mathrm{g})$ 
TMDI $\%=\Sigma \%$ ADI of all registered crops

\section{$208 \quad$ Results and discussion}

Method validation

Satisfactory linearity was achieved with good coefficient values of determination $\left(r^{2} \geq 0.998\right)$ in all cases. Accuracy and precision were also evaluated by the recovery rate (\%) and relative rates $(70 \%-130 \%)$ were achieved with $\mathrm{RSD} \leq 20 \%$, indicating the accuracy and precision of the method. The recoveries of fenpyroximate were $72.0 \% \pm 2.4 \%$ at $0.1 \mathrm{mg} / \mathrm{kg}$ and $77.8 \% \pm$ $1.1 \%$ at $0.5 \mathrm{mg} / \mathrm{kg}$. The recoveries were $78.6 \% \pm 4.8 \%$ at $0.1 \mathrm{mg} / \mathrm{kg}$ and $84.7 \% \pm 1.9 \%$ at 0.5 $\mathrm{mg} / \mathrm{kg}$ for acequinocyl, and $95.6 \% \pm 3.6 \%$ at $0.1 \mathrm{mg} / \mathrm{kg}$ and $83.9 \% \pm 1.0 \%$ at $0.5 \mathrm{mg} / \mathrm{kg}$ for acequinocyl-OH.

\section{Dissipation of acequinocyl and acequinocyl-OH in butterburs}

The analytical method was successfully applied for the analysis of acequinocyl and acequinocyl-OH in butterburs collected from the greenhouse. Neither compound was detected in the control samples from the untreated plot. The concentrations and dissipation rates of acequinocyl and acequinocyl-OH residues in butterburs are listed in Table 2. It was observed that acequinocyl residue levels decreased steadily over time, likely due to the fact that the duration from the last application of the pesticide to the final harvest date increased in both plots $\mathrm{A}$ and B. Concentrations of acequinocyl and acequinocyl-OH in butterburs harvested from Plot A (21 days before harvest) were $5.89 \pm 0.31 \mathrm{mg} / \mathrm{kg}$ and $0.31 \pm 0.01 \mathrm{mg} / \mathrm{kg}$, respectively, immediately after the pesticide application. Final concentrations of acequinocyl and acequinocyl-OH in the butterburs were $0.22 \pm 0.03 \mathrm{mg} / \mathrm{kg}$ and $0.03 \pm 0.01 \mathrm{mg} / \mathrm{kg}$, respectively. Concentrations of acequinocyl and acequinocyl-OH in butterburs grown in plot B (7 days before harvest) were $5.47 \pm 0.27 \mathrm{mg} / \mathrm{kg}$ and $0.25 \pm 0.01 \mathrm{mg} / \mathrm{kg}$, respectively, 
immediately after the pesticide was applied. Final concentrations of acequinocyl and acequinocyl-OH in the butterburs were $1.31 \pm 0.41 \mathrm{mg} / \mathrm{kg}$ and $0.07 \pm 0.01 \mathrm{mg} / \mathrm{kg}$, respectively. Acequinocyl residues in butterburs dissipated by $76.1 \%$ at 7 days after application in plot B and $96.5 \%$ at 14 days after the final application in plot A. Acequinocyl-OH residues in butterburs dissipated $90.3 \%$ at 14 days after the final application in plot $\mathrm{A}$ and by $72.0 \%$ at 7 days after application in plots B. These data indicated that acequinocyl was scarcely converted into its metabolite, acequinocyl-OH, after pesticide application to the plants.

\section{Concentration dissipation of fenpyroximate in butterburs}

Fenpyroximate residues in butterburs harvested from the greenhouse were also successfully analyzed using the optimized method. No pesticide residue was detected in the samples from the untreated control plots. Table 2 lists the concentrations and dissipation rates of the fenpyroximate residue. It was also observed that the residue levels gradually reduced over time, as the duration from the last application of the pesticide to the final harvest date increased in both plots A and B. Concentrations of the target pesticide in butterburs harvested after pesticide application in plot A were $5.07 \pm 0.12 \mathrm{mg} / \mathrm{kg}$. The concentration of the target compound in butterburs collected 21 days before harvest was $0.45 \pm 0.05 \mathrm{mg} / \mathrm{kg}$. The concentrations of fenpyroximate in butterburs harvested from plot B (7 days before harvest) were $3.24 \pm 0.12$ $\mathrm{mg} / \mathrm{kg}$ immediately after the pesticide was applied. The final concentrations in the butterburs were $1.76 \pm 0.03 \mathrm{mg} / \mathrm{kg}$. Fenpyroximate residues in butterburs dissipated by $91.1 \%$ at 14 days after the final application in plot A (double dose) and by $45.7 \%$ at 7 days after application in plot B (single dose).

\section{Dissipation pattern of fenpyroximate, and $\Sigma$ acequinocyl in butterburs}

Dissipation rates of pesticide active substances on or within different plant matrices (e.g., fruits, seeds, stems, and leaves) are important for setting MRLs and various risk assessments (Farha et al. 2016). For instance, farmers can use the application rates to determine when to safely 
re-enter greenhouses or fields after spraying pesticides, to predict pesticide residue concentrations in the agricultural produce for consumer safety, and to determine the time interval required between pesticide application and harvest in order to minimize residue levels (Lee et al. 2019a). Therefore, the plant matrix half-life, calculated based on the dissipation rates, is often an essential input factor in various risk assessment models (Caboni et al. 2004).

Fig. 2a shows the curve for $\Sigma$ acequinocyl, the sum of acequinocyl and acequinocyl-OH residues in butterburs, cultivated in this study. The equation for dissipation of the total acequinocyl was obtained as $\mathrm{C}=7.2539 \mathrm{e}^{-0.23 t}$ with the correlation coefficients $\left(r^{2}\right)$ of 0.9738 . The DT50 value was $3.0 \mathrm{~d}$ for the $\Sigma$ acequinocyl, which is highly similar to a previous study, showing that the DT50 value for $\Sigma$ acequinocyl on perilla leaf plants ranged from 2.8 to 3.1 days (Na et al. 2012). The environmental persistency of acequinocyl has been reported as 3 days (Dekeyser 2005)

The curve for the fenpyroximate residues observed in the butterburs is shown in Fig. 2b. The equation for the dissipation of fenpyroximate was obtained as $\mathrm{C}=5.3719 \mathrm{e}^{-0.173 t}$ with an $r^{2}$ of 0.9769 and a DT50 value of 4.0 days. This result showed that fenpyroximate may be slowly degraded in butterburs, compared with the results observed in a previous study that reported the $\mathrm{DT}_{50}$ value for both treatments as approximately 3.5 days for fenpyroximate on grapes in an open field (Malhat et al. 2013). It has been reported that the DT50 value of fenpyroximate in soil ranges from 30 to 159 days (EFSA European Food Safety Authority 2013). These results indicated that fenpyroximate persists less in plants persists compared to that in soil.

Various factors, including the stability of the parent compounds or metabolites, formulation, solubility, volatility, and pesticide application manner and site factors, can affect pesticide persistence (Farha et al. 2016). Further, pesticide persistence can be affected by several environmental factors, such as temperature, precipitation (and humidity), and air movement (Fenoll et al. 2009). Other factors, including plant properties, the nature of the harvested crop, 

structure of the cuticle, stage and rate of growth, the relationship between treated surfaces and their weight, and the living state of the plant surface, affect the persistence of target pesticides. 


\section{Risk assessment}

The $\%$ ADIs of $\Sigma$ acequinocyl and fenpyroximate in butterburs consumed by Koreans are shown in Table 3. Based on the data provided by the Korean Health Industry Development Institute, Koreans above 12 years of age usually consume butterburs. Out of the four adult groups, the group aged from 12 to 18 years exhibited the lowest \%ADIs of $\Sigma$ acequinocyl $(0.05 \%)$ and fenpyroximate $(0.1 \%)$, and the group aged from 50 to 64 years showed the highest \%ADIs of $\Sigma$ acequinocyl (4.7\%) and fenpyroximate (8.8\%). Two groups (aged 30-49 and >65 years) showed similar \%AD values $(2.35 \%-2.87 \%$ for $\Sigma$ acequinocyl and $4.39 \%-5.38 \%$ for fenpyroximate). The \%ADI values of the target pesticides differed from those of pesticides used on other vegetables consumed by Koreans. In the case of fluxapyroxad and penthiopyrad in perilla leaves consumed by Koreans, all the adult groups showed similar \%ADIs $(6.0 \%-7.2 \%$ and $0.9 \%-1.0 \%$ for fluxapyroxad and penthiopyrad, respectively) (Noh et al. 2019). Because butterburs are receiving attention from Koreans as a health food, its consumption is still restricted to people who are more interested in healthy food and fresh vegetables. It is specified that when \%ADI is $<10 \%$, the relative risk of the target pesticide is low, and further analysis is no longer required (Chun \&Kang 2003). For $10 \leq \%$ ADI $\leq 30$, the pesticide residue concentration poses no significant health risk. In the present study, the maximum $\%$ ADI was $4.71 \%$ for acequinocyl and $8.81 \%$ for fenpyroximate (Table 3). TMDIs of $\Sigma$ acequinocyl and fenpyroximate were $24.02 \%$ and $15.24 \%$, respectively (Supplementary Table 1 and 2). Thus, it can be concluded that the acequinocyl and fenpyroximate residue concentrations in butterburs pose no significant health risks to Koreans. 


\section{Conclusions}

307 In this study, we determined the concentrations of acequinocyl and its metabolite and fenpyroximate residues in butterburs using simple extraction combined with HPLC. The DT50 of fenpyroximate (4.0 days) and total acequinocyl (3.0 days) during the butterbur cultivation experiment were calculated and compared with previous studies. By providing a database for setting up the management and regulation of pesticide use for the cultivation of butterburs and risk assessment data (the maximum \% ADI and TMDIs) for both pesticides, this study would contribute to sustainable production of the minor crops that plays important roles in increasing agricultural productivity and providing diverse food and food security in South Korea. Based on the results, MRLs for fenpyroximate and acequinocyl were set to be $5.0 \mathrm{mg} / \mathrm{kg}$ and 7.0 $\mathrm{mg} / \mathrm{kg}$, respectively. It was determined that acequinocyl (15\%) and fenpyroximate (5\%) can be applied twice or less, 7 days before harvest, to adhere to the guidelines for safe pesticide use. numbers of pesticides for minor crops should be continued.

Given the high market value of minor crops for farmers, various studies on the sufficient$$
\text { Funding (acknowledgement) }
$$

This study was supported by "the RDA Research Associate Fellowship Program of National Institute of Agricultural Sciences" and, "Research Program for Agricultural Science \& Technology Development (PJ01224902)" Rural Development Administration, Republic of Korea.

\section{Conflict of interest}

The authors declare no conflict of interest with this study.

\section{Ethical Approval}

Not Applicable

\section{Consent to Participate.}

We all the writers consent to participate.

\section{Consent to Publish}

We all the writers consent to publish this manuscript. 


\section{Authors Contributions}

Leesun Kim; Experiments and writing manuscript

Geun-Hyoung Choi; Data processing

Hyun Ho Noh; Data processing

Taek-Gyum Kim; Data processing

Dal-Soon Choi; manuscript overview

Kee Sung Kyung; manuscript overview

Jin-ho Ro; Project manager and manuscript overview

\section{Availability of data and materials}

Not Applicable

\section{References}

Caboni P, Sarais G, Melis M, Cabras M, Cabras P (2004): Determination of acequinocyl and hydroxyacequinocyl on fruits and vegetables by HPLC-DAD. J Agric Food Chem 52, $6700-2$

Chun OK, Kang HG (2003): Estimation of risks of pesticide exposure, by food intake, to Koreans. Food Chem. Toxicol. 41, 1063-1076

Dekeyser MA (2005): Acaricide mode of action. Pest Manag. Sci. 61, 103-110

EFSA European Food Safety Authority (2013): Conclusion on the peer review of the pesticide risk assessment of the active substance fenpyroximate. EFSA Journal 11

EFSA European Food Safety Authority (2016): Modification of the existing maximum residue level for acequinocyl in gherkins. EFSA Journal 14, 4568

Farha W, Abd El-Aty AM, Rahman MM, Shin H-C, Shim J-H (2016): An overview on common aspects influencing the dissipation pattern of pesticides: a review. Environ Monit Assess 188,693

Fenoll J, Ruiz E, Hellín P, Lacasa A, Flores P (2009): Dissipation rates of insecticides and fungicides in peppers grown in greenhouse and under cold storage conditions. Food Chem 113, 727-732

Hwang K-W, Bang W-S, Jo H-W, Moon J-K (2015): Dissipation and removal of the etofenprox residue during processing in spring onion. J Agric Food Chem 63, 6675-6680

KHIDI Korea Health Industry Development Institute 2016: National food \& nutrition statistics I: based on 2014 Korea national health and nutrition examination survey.

Kim Y-A, Abd El-Aty AM, Rahman MM, Jeong JH, Shin H-C, Wang J, Shin S, Shim J-H 
(2018): Method development, matrix effect, and risk assessment of 49 multiclass pesticides in kiwifruit using liquid chromatography coupled to tandem mass spectrometry. J. Chromatogr. B 1076, 130-138

Lamichhane JR, Arendse W, Dachbrodt-Saaydeh S, Kudsk P, Roman JC, van Bijsterveldt-Gels JEM, Wick M, Messéan A (2015): Challenges and opportunities for integrated pest management in Europe: A telling example of minor uses. Crop Prot 74, 42-47

Lee J, Jung MW, Lee J, Lee J, Shin Y, Kim J-H (2019a): Dissipation of the insecticide cyantraniliprole and its metabolite IN-J9Z38 in proso millet during cultivation. Sci. Rep. 9, 11648

Lee JS, Jeong M, Park S, Ryu SM, Lee J, Song Z, Guo Y, Choi J-H, Lee D, Jang DS (2019b): Chemical constituents of the leaves of butterbur (Petasites japonicus) and their antiInflammatory effects Biomolecules 9, 806

Lee M-G (2013): Management and regulation on the minor use of pesticides in Korea and foreign countries. Korean J Pestic Sci 17, 231-236

Malhat F, El-Mesallamy A, Assy M, Madian W, Loutfy NM, Ahmed MT (2013): Residues, half-life times, dissipation, and safety evaluation of the acaricide fenpyroximate applied on grapes. Toxicol Environ Chem 95, 1309-1317

Marcic D (2012): Acaricides in modern management of plant-feeding mites. J Pest Sci 85, 395408

Matsuura H, Amano M, Kawabata J, Mizutani J (2002): Isolation and measurement of quercetin glucosides in flower buds of Japanese butterbur (Petasites japonicus subsp. gigantea Kitam.). Biosci Biotechnol Biochem 66, 1571-5

Na TW, Rahman MM, Park J-H, Yang A, Park KH, Abd El-Aty AM, Shim J-H (2012): Residual pattern of acequinocyl and hydroxyacequinocyl in perilla leaf grown under greenhouse conditions using ultra performance liquid chromatography-photo diode array detector with tandem mass confirmation. J Korean Soc Appl Bi 55, 657-662

Noh HH, Lee JY, Park HK, Lee JW, Jo SH, Lim JB, Shin HG, Kwon H, Kyung KS (2019): Dissipation, persistence, and risk assessment of fluxapyroxad and penthiopyrad residues in perilla leaf (Perilla frutescens var. japonica Hara). PLoS one 14, e0212209

OECD (2014): OECD guidance document on defining minor uses of pesticides

Park CH, Kim MY, Sok DE, Kim JH, Lee JH, Kim MR (2010): Butterbur (Petasites japonicus Max.) extract improves lipid profiles and antioxidant activities in monosodium Lglutamate-challenged mice. J Med Food 13, 1216-23

Prevention KCfDCa (2011): Development of dietary assessment report format for the study 

subjects of Korean national health and nutrition examination survey (KNHANES).

Seo H-S, Chung B-H, Cho Y-G (2008): The antioxidant and anticancer effects of butterbur (Petasites japonicus) extracts. Korean J. Plant Res. 21(4), 265-269

Suh E, Koh S-H, Lee J-H, Shin K-I, Cho K (2006): Evaluation of resistance pattern to fenpyroximate and pyridaben in Tetranychus Urticae collectedfrom greenhouses and apple orchards using lethal concentration-slope relationship. Exp Appl Acarol 38, 151165

USDA FAS 2018: Implementation of positive list system for maximum residue limits

Yorulmaz Salman S, Sarıtaş E (2014): Acequinocyl resistance in Tetranychus urticae Koch (Acari: Tetranychidae): inheritance, synergists, cross-resistance and biochemical resistance mechanisms. Int J Acarold 40, 428-435 
416 Table legends

417 Table 1 Recoveries of fenpyroximate, acequinocyl and acequinocyl-OH in butterburs

418 Table 2 Concentrations and dissipation of acequinocyl and acequinocyl-OH and 419 fenpyroximate in butterburs in plots $\mathbf{A}$ and $\mathbf{B}$.

420 Table 3 \% ADI for the risk assessment of fenpyroximate and acequinocyl in butterburs 421 for Koreans by age. 
422 Fig. 1 Experimental design to investigate degradation patterns of acequinocyl, acequinocyl-OH, and fenpyroximate during butterbur cultivation

Fig. 2 Dissipation rate of (a) acequinocyl and acequinocyl-OH and (b) fenpyroximate 



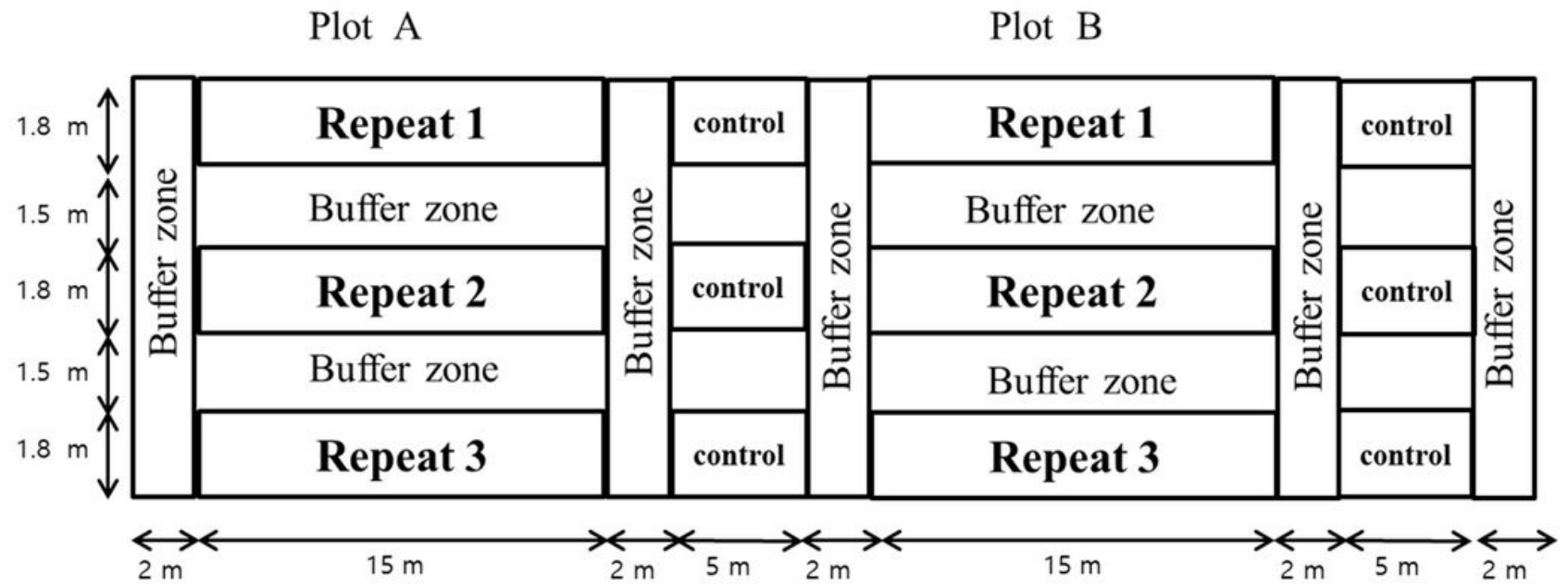

Figure 1

Experimental design to investigate degradation patterns of acequinocyl, acequinocyl-OH, and fenpyroximate during butterbur cultivation
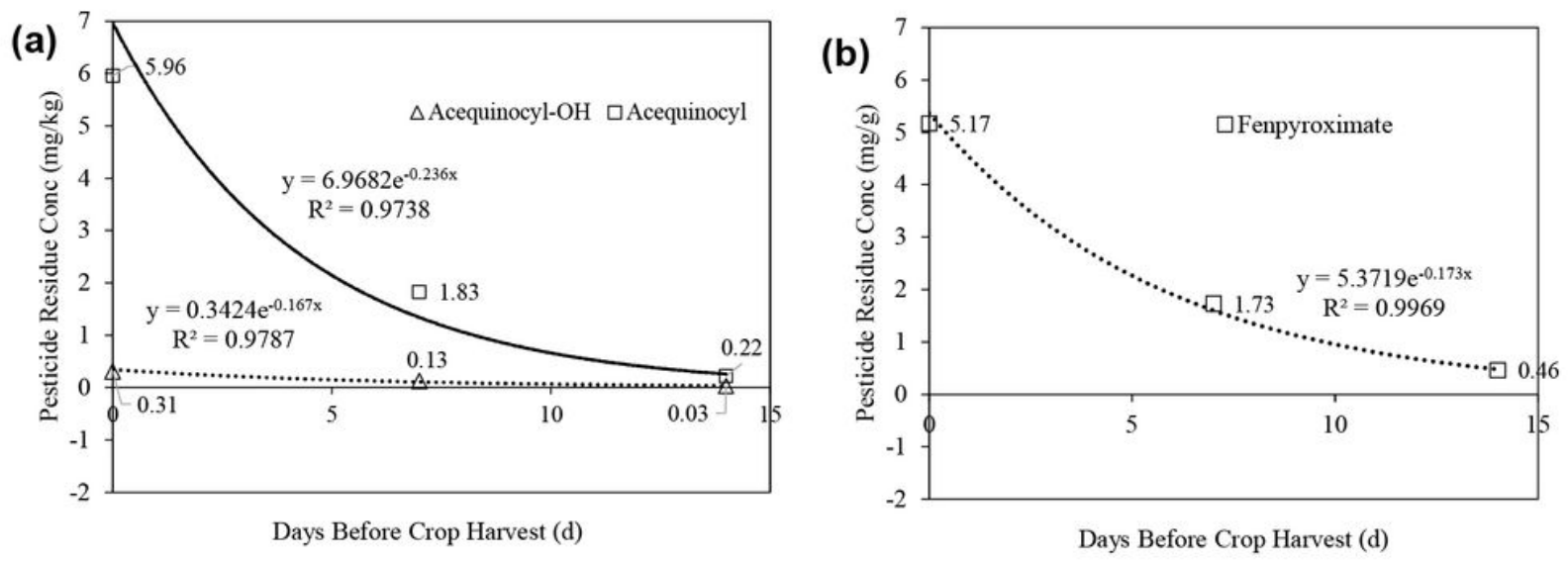

Figure 2

Dissipation rate of (a) acequinocyl and acequinocyl-OH and (b) fenpyroximate

\section{Supplementary Files}

This is a list of supplementary files associated with this preprint. Click to download. 